\title{
SEgurança Contra Intrusão HABITAÇÃO
}

\section{INTRODUÇÃo}

O crescente aumento da criminalidade, com especial incidência nos crimes contra a propriedade, levou a um forte incremento na procura e instalação de Sistemas Automáticos de Detecção de Intrusão (SADI).

A instalação de um SADI não pode ser analisada numa perspectiva exclusivamente monetária, ignorando-se uma série de outros aspectos, como por exemplo, o facto de, aquando de um assalto, além do roubo e/ou vandalismo de bens de elevado valor comercial, poder ocorrer também o roubo e/ou vandalismo de bens de baixo valor comercial, mas de elevado valor sentimental, além de que podem também ocorrer danos físicos e/ou psicológicos nos ocupantes das instalações.

A instalação de um SADI torna-se, assim, fundamental como elemento de garantia do bem-estar e da segurança das pessoas, velando pela sua salvaguarda e pela salvaguarda dos seus bens, fazendo hoje (quase), obrigatoriamente, parte dos sistemas aplicados no sector da habitação, serviços, comércio e indústria.

A instalação de sistemas automáticos de detecção de intrusão tornou-se, deste modo, hoje em dia, uma necessidade e um facto generalizado, em todos os sectores de actividade, desde o comércio, serviços, industria até á habitação, motivado, por um lado, pela necessidade de proceder à protecção de pessoas e bens, mas também, pela confiabilidade e baixo preço destes sistemas.

\section{Constituição de Um Sistema de Detecção de INTRUSÃo}

Um sistema automático de detecção de intrusão é um sistema que automaticamente detecta e sinaliza uma tentativa de intrusão.
É um equipamento ou conjunto de equipamentos integrados entre si, com o intuito de vigiar determinado espaço e, que em caso de intrusão (tentativa de entrada concretizada ou não), accione meios sonoros (Sirene), luminosos (Flash) ou ainda electrónicos (Comunicadores Telefónicos, ligados ou não a Centrais de Recepção de Alarmes, etc), com vista à dissuasão dos actores do acto.

Tipicamente, um SADI para uma moradia é constituído por uma central de intrusão por zonas, com um número de zonas de acordo com as dimensões e características arquitectónicas da instalação, um ou vários painéis de comando do sistema localizados nas entradas/saídas, detectores automáticos normalmente passivos de infravermelhos ou de dupla tecnologia, contactos de alarme e meios de sinalização, regra geral uma sirene óptico acústica auto alimentada de exterior e uma sirene acústica de interior, bem como, um sistema de transmissão do alarme, normalmente um comunicador telefónico.

A figura 1, mostra a arquitectura geral de um sistema de detecção automática de intrusão.

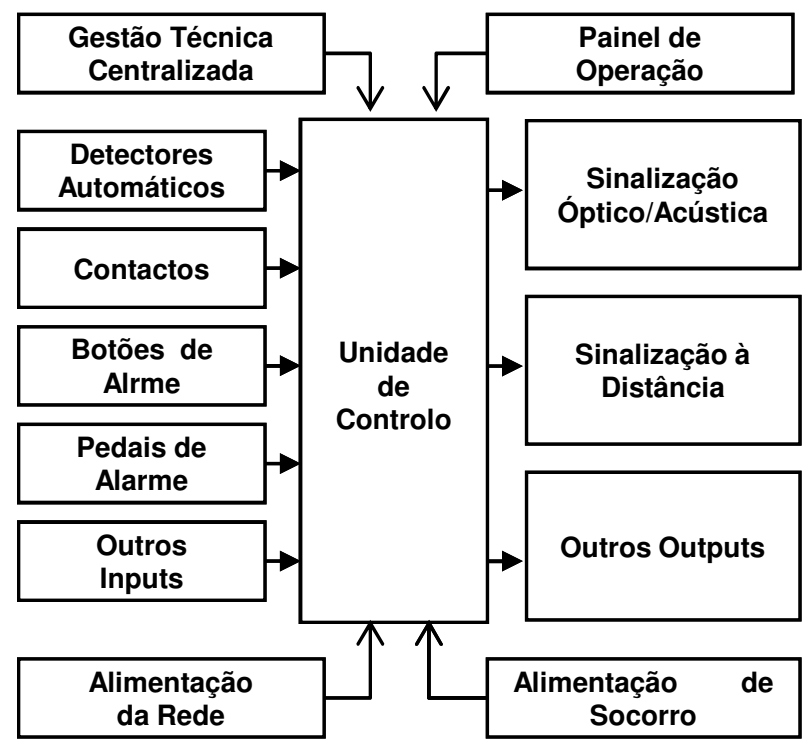

Figura 1 - Constituição geral de sistema um SADI 


\subsection{Central de Intrusão}

A Central de Intrusão $(\mathrm{Cl})$ é o cérebro de todo o sistema. É a este equipamento que são ligados todos os periféricos (Detectores, Painéis de Operação, Sirenes, ...) e, a partir do qual poderá ser enviada uma ordem de acção, em função dos dados recebidos dos periféricos.

\subsubsection{Selecção do Tipo de Central}

A selecção do tipo de Central de Intrusão é um aspecto fundamental para realizar uma eficaz protecção das instalações e deverá ser realizada de acordo com o tipo de instalação que se está a projectar.

Os principais elementos a ter em conta na escolha da central de intrusão, são: o número de zonas de base, a possibilidade de expansão do número de zonas, o número de painéis de operação necessários, a capacidade de registo em memória de eventos, a possibilidade de integração com sistemas de gestão centralizada, a fiabilidade e, obviamente, o preço bem como a estética do equipamento.

O tipo e a capacidade da $\mathrm{Cl}$ deverão, assim, ser escolhidos em função dos parâmetros anteriormente mencionados, destacando-se de entre todos a dimensão da instalação a proteger e o número de zonas requeridas pelo sistema.

Com efeito, para instalações de pequena/média dimensão, são normalmente utilizadas centrais por zonas, onde cada zona deverá corresponder a uma área protegida. Existem no mercado variadas gamas com 4, 6, 8, 10, 12 e 16 zonas, podendo mesmo chegar às centenas de zonas.

Para instalações de média/grande dimensão, cujos sistemas requeridos são, normalmente, de maior dimensão e mais complexos, sendo necessárias um número bastante elevado de zonas e em que as distâncias dos locais a proteger à Central de Intrusão possam ser significativas, será vantajosa a utilização de sistemas endereçáveis. Estes sistemas contemplam a existência e um bus onde estarão ligadas as zonas por meio de interfaces de endereçamento conseguindo-se, assim, soluções mais funcionais e mais fáceis de gerir. Embora este equipamento seja mais caro, quando comparado com o equipamento dos sistemas de zonas, a possibilidade de economia em cablagem e em mão-de-obra, aquando da realização da instalação, contribui para uma atenuação do diferencial de custos.

\subsubsection{LOCALIZAÇÃo}

A localização da $\mathrm{Cl}$ dependerá essencialmente do facto de esta ter, ou não, painel de comando incorporado.

Se a $\mathrm{Cl}$ não tiver painel de controlo incorporado, que é o caso mais frequente, esta poderá e deverá ser instalada numa zona técnica, em local seguro e protegido, já que depois de realizada a sua cablagem e programação, todas as restantes operações estarão disponíveis nos painéis de controlo.

Se a $\mathrm{Cl}$ tiver painel de comando incorporado, como é o caso de pequenos sistemas, esta deverá ficar localizada num lugar de fácil acesso que permita, além da sua cablagem e programação, um acesso fácil aos futuros utilizadores do sistema.

\subsubsection{SelecÇão do tiPo d E ZoNA}

Embora possam variar de fabricante para fabricante de equipamento, de uma forma geral, são consideradas as seguintes funcionalidades das zonas de detecção:

- Zona de Intrusão

- Instantânea

Quando o sistema se encontra "activado" esta zona tem um funcionamento instantâneo.

- Entrada/saída

- Seguimento de zonas de entrada/saída

- Zona de Pânico

- Zona de Ataque

- Zona de Incêndio

- Zona de Sabotagem

- Zona Técnica (Gás, Inundação, Humidade, Temperatura,...) 
A programação da funcionalidade da zona deverá ser realizada de acordo com a finalidade da mesma. Dependendo do tipo de equipamento, esta poderá ser realizada através do painel de operação e/ou através de software via computador.

\subsection{Painel de Operação}

Os Painéis de Operação são os equipamentos que permitem o acesso ao sistema, quer para programação, quer para utilização.

Em pequenos sistemas, os Painéis de Operação podem encontrar-se integrados na própria Central de Intrusão, reunindo-se desta forma a central e o painel de operação num só equipamento. No entanto, o mais vulgar é que a central e os painéis se encontrem separados, sendo estes interligados e instalados em diversos locais da instalação.

O acesso aos Painéis de Operação deve ser protegido por códigos de segurança, que inibam as entradas indevidas no sistema. Normalmente, existem códigos diferenciados para "Código Mestre", que tem acesso a todas as funções, com excepção da programação do sistema, "Código Engenheiro", com acesso à programação e testes do sistema e "Códigos de Utilizador" que usualmente tem acesso a armar e desarmar o sistema, leitura de incidências, alarme parcial e inibição de zonas.

Existe também a possibilidade de, em situações particulares, permitir o aceso ao sistema através de chave, dispositivo codificado via rádio ou via infravermelhos.

O número de Painéis de Controlo que poderão ser utilizados depende das características da $\mathrm{Cl}$ que estiver a ser utilizada. Sendo Os Painéis de Controlo o interface utilizador/sistema, são uma parte importantíssima do sistema. Por isso, deverão estar localizados em locais com acesso fácil e rápido, dentro do(s) percurso(s) normais de entrada (entrada principal, garagem, etc. ), de forma a que o tempo necessário para activação e desactivação do alarme seja o mais curto possível.

\subsection{Detectores Automáticos}

Os Detectores automáticos são os "olhos" do sistema, são eles os elementos responsáveis pela detecção da tentativa de intrusão e respectiva comunicação à Central de Intrusão.

O princípio de funcionamento dos detectores e a filosofia de detecção a utilizar, vai determinar a escolha correcta dos detectores de intrusão.

\subsubsection{CLASSIFICAÇÃO QUANTO AO PRINCíPIO DE FUNCIONAMENTO}

Os detectores automáticos agrupam-se em dois grandes grupos de acordo com o seu princípio de funcionamento:

- Passivos, que funcionam como receptores e que através de um sensor, registam alterações na sua área de cobertura. São exemplo deste tipo de detectores, os detectores passivos de infravermelhos, detectores acústicos de quebra de vidros e os detectores sísmicos.

- Activos, que funcionam como um transmissor e um receptor, sendo que o transmissor envia um sinal ao receptor, que o recebe e avalia, determinado nível de variação em relação a um valor padrão origina o envio de um sinal para a central. Transmissor e receptor, podem constituir elementos separados, ou estar incluídos numa mesma unidade. São exemplo deste tipo de detectores, as Barreiras de infravermelhos, os detectores ultra-sónicos e os detectores de micro-ondas.

\subsubsection{PRINCÍPIO DE FUNCIONAMENTO}

\section{- Detectores Passivos de Infravermelhos}

São os detectores automáticos, mais utilizados, pois permitem realizar a protecção de uma forma eficiente em praticamente todas as situações.

O seu princípio de funcionamento baseia-se no facto de todos os elementos (paredes, mobiliário, animais, corpo humano, etc.) irradiarem energia na zona do infravermelho, de acordo com a temperatura das suas superfícies. 
Essa energia é recebida por um sensor piroeléctrico colocado no detector, através de zonas de vigilância, criando aquando do arme do sistema uma imagem da quantidade de infravermelho no espaço de vigilância.

Quando alguém penetra na zona de vigilância do detector, a temperatura medida sofre alteração, gerando-se então o sinal de alarme.

A geração do sinal de alarme, é feita pela temperatura medida e pela taxa de variação desta temperatura.

Estes detectores, embora sendo os mais baratos, poderão, em certas situações particulares, não garantir o melhor funcionamento do sistema e provocar alarmes intempestivos, como é o caso da protecção de locais em que possam existir fontes de calor (lareiras, radiadores) ou janelas com a incidência directa do sol que poderão variar bruscamente de temperatura.

A existência de falsos alarme é um factor decisivo para a perda de confiança e descrédito no sistema, pelo que deverá ser sempre minimizado, através da escolha certa do tipo de detector a utilizar, em função das suas condições particulares de implementação.

Assim, em instalações onde se possam verificar qualquer uma das situações anteriormente descritas, recomenda-se a utilização de detectores de dupla tecnologia (Passivos de Infravermelhos e de Micro Ondas), que permitem minimizar a possibilidade de falsos alarmes.

\section{- Detectores de Dupla Tecnologia (Passivos de Infravermelhos e de Micro-Ondas)}

A actuação de um detector de dupla tecnologia, assenta na combinação dos dois sinais de alarme, do detector passivos de Infravermelhos e do detector de micro-ondas, reduzindo assim o risco dos falsos alarmes anteriormente referidos.
O princípio de funcionamento do detector passivo de infravermelhos já foi referido anteriormente. Relativamente ao princípio de funcionamento de um ultra-sónico de movimento, baseia-se na existência de um transmissor que envia continuamente ondas sonoras a frequências não audíveis para a área de detecção.

Um receptor dotado de um microfone, recebe e avalia a frequência detectada.

Se algum elemento (pessoa, animal, objecto, etc.), penetrar na área de protecção do detector, devido ao Efeito Doppler, vai verificar-se um aumento de frequência do sinal emitido, se o intruso se aproximar do detector e uma diminuição, caso se esteja a afastar. 0 detector ao detectar a alteração da frequência do sinal, gera a informação de alarme.

\section{- Detectores Acústicos de Quebra de Vidros}

Para situações particulares, nomeadamente para protecção periféricam, poderá ser utilizado outro tipo de detectores, sendo os mais usuais os detectores acústicos de quebra de vidros.

O seu princípio de funcionamento baseia-se na existência de uma superfície em contacto com o vidro, por onde são transmitidas a um sensor piezoeléctrico, as vibrações desse mesmo vidro.

Aquando de uma tentativa de intrusão, quando o vidro se parte, gera frequências entre os $0,1 \mathrm{MHz}$ e $1 \mathrm{MHz}$. O sensor do detector avalia a amplitude, frequência e duração desse sinal, gerando o alarme, quando se ultrapassam certos valores, pré-definidos.

\section{- Barreiras de Infra-vermelhos}

São constituídas por um transmissor e um receptor. O receptor emite para o receptor, um feixe de luz na zona do infravermelho, modulado, para protecção contra luz exterior. 
O receptor mede a intensidade e frequência do feixe, podendo ainda medir também a sua fase.

Ao haver interposição de um corpo entre o transmissor e o receptor, as características do feixe são alteradas ou o feixe é interrompido, o que gera sinalização de alarme.

São normalmente utilizadas para a vigilância de corredores, passagens, paredes, janelas, portas, etc..

Existem, também, versões para utilização no exterior, para a realização de uma protecção perimétrica, mas a sua utilização pode originar falsos alarmes, por exemplo, devido à presença de nevoeiro.

\section{- Cabo Electrostático Subterrâneo}

É composto por um par de cabos enterrados, em cuja malha existem pontos favoráveis ao estabelecimento de um campo electromagnético (sinal de $40 \mathrm{MHz}$ ), que se estabelece ente os dois, um o transmissor e outro o receptor.

A entrada de um intruso, provoca alteração no corpo electromagnético, que conduz á sinalização de alarme.

É utilizado para protecção perimétrica, sendo imune aos fenómenos atmosféricos, como por exemplo o nevoeiro e o vento.

\section{- Outros Detectores Automáticos}

Além dos detectores anteriormente descritos, ocupam um lugar privilegiado na detecção de intrusão, existe, no mercado uma vasta gama de detectores, nomeadamente, para detecção em condições muito especificas, para as quais os detectores anteriormente descritos não são apropriados. Dentre esses detectores destacamos:

- Barreiras de micro-ondas

- Detectores ultra-sónicos de movimento

- Detectores movimento por microondas

- Detectores sísmicos
- Detectores de pressão para vitrinas

- Sistema de protecção de quadros

- Detectores quebra-vidros

- Detectores de vibrações

- Detectores de metais

- Sistemas de raio $X$

De entre este conjunto de detectores, os normalmente, mais utilizados são os detectores passivos de infravermelhos e os detectores de dupla tecnologia (Passivos de Infravermelhos e de Micro Ondas), pois permitem realizar a protecção de uma forma eficiente em praticamente todas as situações.

Contudo, para situações particulares poderá ser utilizado outro tipo de detectores, sendo os mais usuais os detectores acústicos de quebra de vidros, detectores sísmicos ou detectores de pressão.

Os detectores passivos de infravermelhos, embora sendo mais baratos que os de dupla tecnologia, poderão, em certas situações particulares, não garantir o melhor funcionamento, como é o caso da protecção de locais em que possam existir fontes de calor (lareiras, radiadores) ou janelas com a incidência directa do sol que poderão variar bruscamente de temperatura. Estas condições poderão provocar alarmes intempestivos.

A localização e instalação dos detectores automáticos serão outros dos aspectos a estudar cuidadosamente, na fase de projecto, pois a sua localização será um factor determinante no correcto funcionamento de todo o sistema.

Conforme foi referido, há que analisar potenciais fontes de calor que poderão interferir no funcionamento do sensor, causando falsos alarmes. Também a presença de animais e as janelas ou vidraças são também aspectos a ter em conta.

A especificação e instalação de um detector deverá atender aos requisitos mencionados na sua ficha técnica, nomeadamente, no que se refere à sua área de protecção, altura de instalação e distância a outros objectos. 
Normalmente os detectores são instalados a uma altura de 2,20 metros e na interligação de duas paredes do volume a proteger.

Relativamente à sua ligação, os detectores possuem a ligação da alimentação vinda da $\mathrm{Cl}$, três contactos de ligação do relé de alarme, "Comum", "Normalmente Aberto" e "Normalmente Fechado" que irão mudar de estado em caso de intrusão e comunicar esse alarme à $\mathrm{Cl}$ e ainda um contacto de tamper que se destina a impedir a sabotagem do detector, quando o sistema se encontra em funcionamento "modo dia" e por conseguinte com a informação de alarme inibida na $\mathrm{Cl}$.

\subsection{Contactos de Alarme}

São, normalmente, utilizados para realizar uma protecção localizada em portas, janelas ou objectos, como complemento à protecção volumétrica de interior, realizada pelos detectores automáticos de intrusão.

São baratos e não provocam falsos alarmes.

\subsubsection{CONTACTOS MAGNÉticos}

São constituídos por um magnete permanente e por um interruptor. Quando o magnete está posicionado junto ao interruptor, este está fechado, não havendo alarme, se o magnete se afastar, o interruptor abre, gerando alarme.

\subsubsection{CONTACTOS DE VIGILÂNCIA}

São constituídos por um micro-interruptor, que quando pressionado, mantém o circuito fechado, não existindo alarme. Se deixar de existir esta pressão, ele abre, gerando o alarme.

Os contactos de alarme são normalmente utilizados para realizar uma protecção localizada em portas, janelas ou objectos e definir temporizações para actuação dos detectores localizados nos percursos de entrada/saída.
Assim, os Contactos Magnéticos e Contactos de Pressão, além de elementos de detecção poderão, também, ter a função acessória de detecção, como complemento à detecção realizada pelos detectores automáticos. No caso de entradas/saídas deverão, assim, ser utilizados os contactos de alarme nas portas para definição da temporização da zona de entrada/saída de forma a que os detectores automáticos dessa zona só tenham uma temporização de actuação se antes for actuado o contacto da porta. Este procedimento visa garantir que se a zona de entrada/saída não for a definida previamente (por exemplo se uma janela for arrombada) o sistema instantaneamente dê o alarme, minimizando os efeitos da tentativa de intrusão ou da intrusão.

\subsection{Botões Manuais e Pedais de Alarme}

Os Botões e Pedais de Alarme são elementos complementarres de protecção, de actuação manual, de complemento à deteç̧ão realizada pelos outros elementos de detecção, cuja actuação será realizada pelos próprios utilizadores do sistema em caso de necessidade, por pânico ou emergência, mesmo quando o sistema se encontra desarmado.

São dispositivos que quando pressionados, actuam um contacto que vai gerar o alarme.

São elementos acessórios de protecção, de actuação manual, de complemento à detecção realizada pelos outros elementos de detecção, cuja actuação será realizada pelos próprios utilizadores do sistema em caso de necessidade.

\subsection{OUTROS INPUTS}

Além dos detectores automáticos, contactos de alarme e botões e pedais de alarme o sistema pode receber outros tipos de informações, caso o utilizador entenda poderem servir de complemento aos elementos descritos. 


\subsection{Sinalizadores de Alarme}

Existem, basicamente, dois tipos de sinalizadores de alarme: os sinalizadores óptico-acústicos auto-alimentados de exterior e os sinalizadores acústicos de interior.

Existem em diversas formas, tamanhos e cores e a sua finalidade é, em caso de alarme, emitirem sinais sonoros e/ou luminosos, sinalizando assim uma situação potencialmente anormal.

Os sinalizadores de alarme óptico-acústicos autoalimentados de exterior têm como função dar um alarme no exterior das instalações para que alguém possa tomar conhecimento do alarme e agir em conformidade com essa mesma situação. Deverão ser instalados em locais bem visíveis e de difícil acesso. Na maioria das instalações é suficiente a instalação de um destes dispositivos.

Para sinalização do alarme no interior da instalação deverá ser prevista a colocação de sirenes interiores, devidamente distribuídas, para que o alarme seja audível em todos os locais da instalação.

A instalação de um alarme sonoro, pressupõe a Declaração de Instalação de Alarme Sonoro, nos termos do DL 297/99, de 04 de Agosto, que refere que após a instalação do sistema de alarme sonoro, e antes da sua colocação em funcionamento, o proprietário ou o utilizador deverá proceder à entrega da Declaração de Instalação de Alarme Sonoro, devendo para isso dirigir-se ao Governo Civil do Distrito onde foi instalado o alarme e entregar a respectiva declaração.

\subsection{SINALIZAÇÃo DE ALARME À DISTÂNCIA}

Tão importante como o alarme local poderá ser a transmissão à distância desse alarme.

A sinalização do alarme à distância dever-se-á utilizar nas seguintes situações:

- A instalação se encontrar isolada
- Se pretender alertar os proprietários quando estes se encontrem ausentes

- Se pretenda a realização de um contrato de vigilância com uma empresa de segurança

- Se pretenda a comunicação da intrusão ou da tentativa de intrusão às forças policiais.

Assim, esta sinalização poderá ser realizada recorrendo a meios de transmissão do alarme, dos quais destacamos:

\section{- Comunicador telefónico}

É o meio mais generalizado e económico de transmissão do alarme à distância. Em caso de alarme a Central de Intrusão envia um sinal ao comunicador telefónico que posteriormente efectua uma ou várias chamadas telefónicas para números pré-definidos para transmissão da informação de alarme. Desta forma, se existir um alarme, o cliente será alertado pelo próprio sistema, podendo assim tomar a atitude que considerar mais adequada (telefonar à polícia, alertar o vizinho, etc.).

\section{- Sistema Transmissor/Receptor}

É um sistema para aviso à distância de qualquer situação de alarme ou avaria, via par telefónico privativo. Embora exija uma linha telefónica dedicada, pode em algumas circunstâncias, ser mais fiável do que o comunicador telefónico, pois não há forma de interromper o sinal sem que tal seja detectado.

É constituído por um órgão emissor de sinal instalado junto da Central de Intrusão e por uma unidade receptora instalada na entidade receptora de alarmes.

O órgão receptor é alimentado pelo órgão emissor via par telefónico privativo, o qual tem energia de socorro garantida pela Central de Intrusão. Incorpora, ainda, uma bateria alcalina para que, em caso de corte de linha telefónica, sinalize óptica e acusticamente a situação. Dispõe, também, de um botão de impulso para paragem do acústico. 
De acordo com o tipo de comunicador utilizado as necessidades ao nível do projecto serão:

- Utilização da rede fixa

Prever a existência de um comunicador e uma linha telefónica

- Utilização da rede móvel

Prever a existência de um comunicador de GSM

- Utilização de um sistema emissor/receptor

Prever a existência de uma linha dedicada e um sistema emissor/receptor

Estes sistemas de transmissão de alarme à distância são normalmente colocados junto da central de detecção de intrusão, em zona técnica prevista para esse efeito.
Além dos meios de sinalização de alarme descritos, podemos ter outros tipos meios, ou o desencadear de outro tipo de acções, caso a instalação assim o exija.

\subsection{ALIMENTAÇÃo}

A alimentação de energia eléctrica do sistema em condições normais de funcionamento deverá ser realizada através da rede de energia eléctrica devendo para o efeito ser prevista uma alimentação vinda do Quadro Eléctrico da instalação.

O sistema deverá ainda ter uma alimentação própria de emergência que garanta o seu funcionamento em caso de falha da alimentação normal da rede.

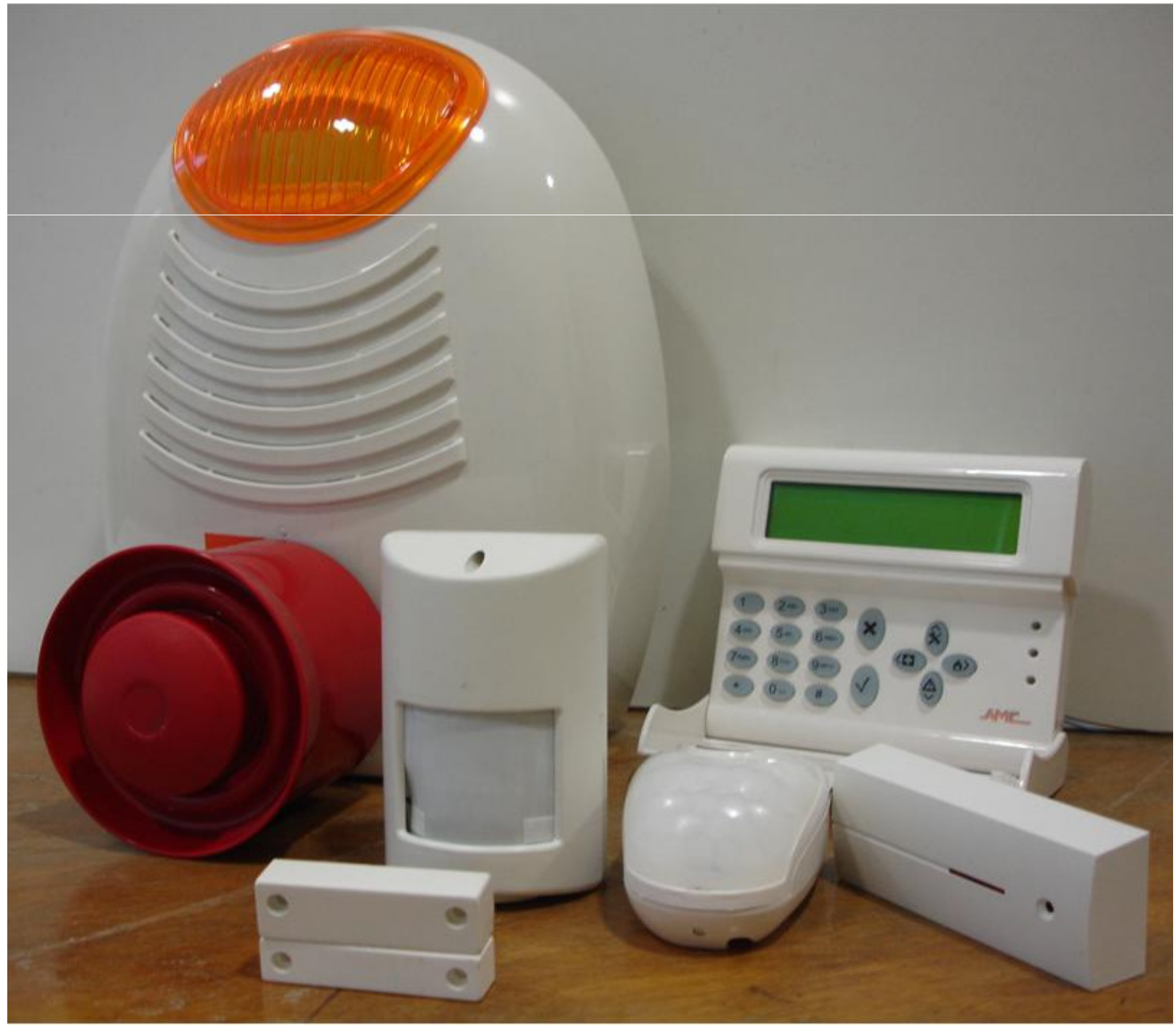

Figura 2 - Equipamento diverso de um sistema de detecção automática de intrusão 


\subsection{CABlagem}

O tipo e número de condutores a utilizar para a interligação dos diversos equipamentos anteriormente apresentados, dependerá do tipo de equipamento que estiver a ser utilizado e, por conseguinte, deverá ser verificado nos manuais de instalação dos equipamentos disponibilizados pelos fabricantes dos mesmos.

No entanto, é usual a utilização dos seguintes condutores:

\section{- Painéis de Comando}

Cabos do tipo TVHV, JY(st)Y, ou equivalentes, com condutores de secções de 0,5 ou 0,8 mm2. Como exemplos teremos os cabos TVHV $6 \times 2 \times 0,5 \mathrm{~mm} 2$ ou JY(st)Y $3 \times 2 \times 0,8$ $\mathrm{mm} 2$.

\section{- Rede de distribuição de detectores automáticos}

Cabos do tipo TVHV, JY(st)Y, ou equivalentes condutores de secções de 0,5 ou 0,8 $\mathrm{mm}^{2}$. Como exemplos teremos os cabos TVHV $3 \times 2 \times 0,5 \mathrm{~mm} 2$ ou JY(st)Y $2 \times 2 \times 0,8 \mathrm{~mm}^{2}$.

\section{- Sirene auto-alimentada de exterior}

Cabos do tipo TVHV, JY(st)Y, ou equivalentes, com condutores de secções de 0,5 ou $0,8 \mathrm{~mm}^{2}$. Como exemplos teremos os cabos TVHV $6 \times 2 \times 0,5 \mathrm{~mm}^{2}$ ou JY(st)Y $3 \times 2 \times 0,8$ $\mathrm{mm}^{2}$.

\section{- Sirene acústica de interior}

Cabos do tipo TVHV, JY(st)Y, ou equivalentes, com condutores de secções de 0,5 ou 0,8 $\mathrm{mm}^{2}$. Como exemplos teremos os cabos TVHV $3 \times 2 \times 0,5 \mathrm{~mm} 2$ ou JY(st)Y $2 \times 2 \times 0,8$ $\mathrm{mm}^{2}$.

Estes circuitos deverão ser, normalmente, enfiados em tubo VD, embebidos em paredes, tectos e pavimento, à vista em abraçadeiras em zonas técnicas, à vista em abraçadeiras sobre tectos falsos, se acessíveis, ou em calha técnica, de acordo com as características da instalação em causa.

Nos locais de montagem dos detectores, sirenes de alarme e painéis de comando, deverá prever-se que as extremidades dos cabos possuam cerca de $20 \mathrm{~cm}$ excedentes, para realização das respectivas ligações.

Igualmente, deverão ser previstas pontas com o comprimento suficiente para a realização das cablagens no interior da $\mathrm{Cl}$, considerando que a sua base se deve situar a 1,40 metros do solo.

Não são permitidas emendas entre condutores nos percursos entre equipamentos e entre estes e a $\mathrm{Cl}$, devendo as interligações entre aqueles equipamentos ser realizadas unicamente a partir dos terminais existentes nas respectivas bases para esse efeito, não devendo se usadas caixas de derivação, mas apenas caixas de passagem, quando necessárias.

Deverá ser prevista uma alimentação de energia eléctrica monofásica, para a $\mathrm{Cl}$, realizada, normalmente, em condutor H07V-U3G1,5 $\mathrm{mm}^{2}$.

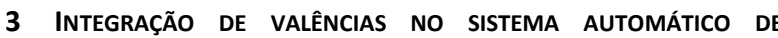
DETECÇÃO DE INTRUSÃo

Cada vez mais os edifícios são centros integrados de tecnologia e sistemas, que visam dar resposta aos requisitos de segurança, de funcionalidade, fiabilidade, flexibilidade, eficiência energética, conforto e de integração, requiridos na sua utilização, mas nos quais a redução dos custos de execução e exploração são cada vez mais determinantes no sucesso dos mesmos.

As moradias não fogem à regra desta evolução, tendo, cada vez mais, uma participação activa na vida das pessoas, sendo cada vez maiores as exigências nos domínios referidos.

Neste sentido, no que se refere à segurança, a protecção de pessoas e bens numa moradia não se deve, nem pode, circunscrever somente à protecção contra tentativas de intrusão, mas também outras áreas importantes como a detecção de incêndio, inundação, gases combustíveis e monóxido de carbono. 
A crescente utilização do gás como fonte de energia, quer para fogões, quer para aquecimento de água e aquecimento ambiente, implica também o crescente perigo da existência de fugas as quais poderão trazer graves consequências quer para os utilizadores quer para as próprias moradias, pois uma fuga de gás pode conduzir a uma intoxicação ou a uma explosão.

Um outro perigo, que nem sempre é encarado conscientemente como um perigo real e presente, é o risco de incêndio, motivado pela enorme quantidade de substâncias combustíveis que se encontram dentro das habitações bem como ao crescente número de equipamentos eléctricos que equipam as mesmas.

A possibilidade de ocorrência de inundações devido ao rebentamento de canos de água ou ao mau funcionamento de equipamentos como máquinas de lavar, máquinas de secar ou ainda pelo esquecimento de uma simples torneira aberta, constitui também uma situação de risco.

Este tipo de situações de risco está sempre presente no nosso dia-a-dia e, não havendo possibilidade de as excluir, podemos com a adopção de sistemas adequados criar condições para que, caso se verifiquem, sejam detectadas e sinalizadas o mais cedo possível de forma a que os danos materiais e pessoais que possam vir a causar sejam minimizados.

Para que se consiga alcançar esse objectivo de forma simples e a baixo custo poder-se-á optar pela integração no sistema de detecção automática de intrusão das diferentes áreas de segurança anteriormente referidas.

A detecção automática de incêndios pode ser integrada neste sistema mediante a utilização de um ou vários detectores automáticos de fumos ou termovelocimétricos, do tipo colectivo, acoplados a uma interface de incêndio, ou através de detectores com contacto "seco" de alarme, ligados a uma ou várias zonas da central de intrusão.
Essa ou essas zonas da central d eintrusão, deverão ser programadas como zonas de fogo. Desta forma, conseguirse-á detectar e sinalizar um incêndio na sua fase inicial facilitando, assim, o combate e extinção do mesmo, minimizando os riscos do mesmo.

A detecção automática de presença de gás poderá ser realizada através da colocação de um ou vários detectores de gás que, encontrando-se interligados a uma ou várias zonas da central de intrusão, informam esta da ocorrência de uma fuga de gás, a qual realizará a sinalização do alarme. Adicionalmente, à sinalização do alarme, poderão ser desencadeadas acções de comando, nomeadamente o fecho de uma electroválvula de corte de gás.

A detecção automática de inundação poderá ser realizada através da colocação de detectores de inundação nos locais com maior risco de fugas de água, como casas de banho e cozinhas. A integração desta valência pode ser realizada através da utilização de módulos de interface, aos quais são ligados os detectores de inundação ou através de detectores de inundação, autonomos, com contacto "seco" de alarme. A informação de inundação é transmitida a uma ou várias zonas da central de detecção de intrusão, que sinalizará o evento. Em complemento com a sinalização da ocorrência poderão ser, também, desencadeadas acções de comando como por exemplo o fecho de uma electroválvula de corte da alimentação de água.

As zonas da central de intrusão previstas para a detecção de presença de gás e inundação deverão ser programadas como zonas "24 horas" de modo a garantir que a protecção se encontra activa 24 horas por dia, independentemente da protecção de intrusão se encontrar activada ou desactivada.

Deste modo consegue-se a integração no sistema de detecção automática de intrusão as valências de detecção de incêndio, gás combustível, monóxido de carbono e inundação de uma forma simples, fiável e económica. 


\section{Conclusões}

Este artigo visou abordar aspectos técnicos e conceptuais, ao nível do projecto e da instalação de Sistemas Automáticos de Detecção de Intrusão.

A escolha e implementação destes sistemas são, hoje em dia, um elemento dissuasor e inibidor da criminalidade contra pessoas e bens.

Actualmente, existe uma panóplia de sistemas e equipamentos em que a sua correcta utilização e instalação requer, à priori, uma colaboração estreita com técnicos devidamente credenciados, nomeadamente Engenheiros Electrotécnicos e empresas especializadas neste sector.

A escolha do melhor sistema e equipamentos requer uma análise cuidada das pretensões do requerente, bem como das especificidades próprias da instalação.

Assim, cada projecto é tratado individualmente, sendo alvo de uma análise cuidada por parte dos técnicos especializados, podendo diferir dos demais projectos.
A consciencialização da necessidade de protecção de pessoas e bens, a par da evolução tecnológica dos equipamentos, proporcionam formas eficazes de detecção e sinalização precoce de tentativas de intrusão e, consequentemente, a protecção dos bens materiais das populações.

Embora estes sistemas representem um pequeno custo adicional ao valor global da instalação deverá ser sempre equacionada a sua instalação uma vez que é relativamente diminuto quando comparado com os potenciais prejuízos decorrentes dos actos que o sistema pretende evitar.

Salienta-se ainda que sempre que se vai projectar, construir ou remodelar uma moradia, além da consideração no sistema de detecção automática de intrusão, da função detecção de intrusão, é fundamental a integração de outras valências de segurança, como a detecção de incêndio, gases combustíveis, monóxido de carbono e inundação.

Essa integração pode ser realizada de uma forma simples e económica, aumentando significativamente a protecção dos utilizadores das instalações e a salvaguarda dos seus bens.

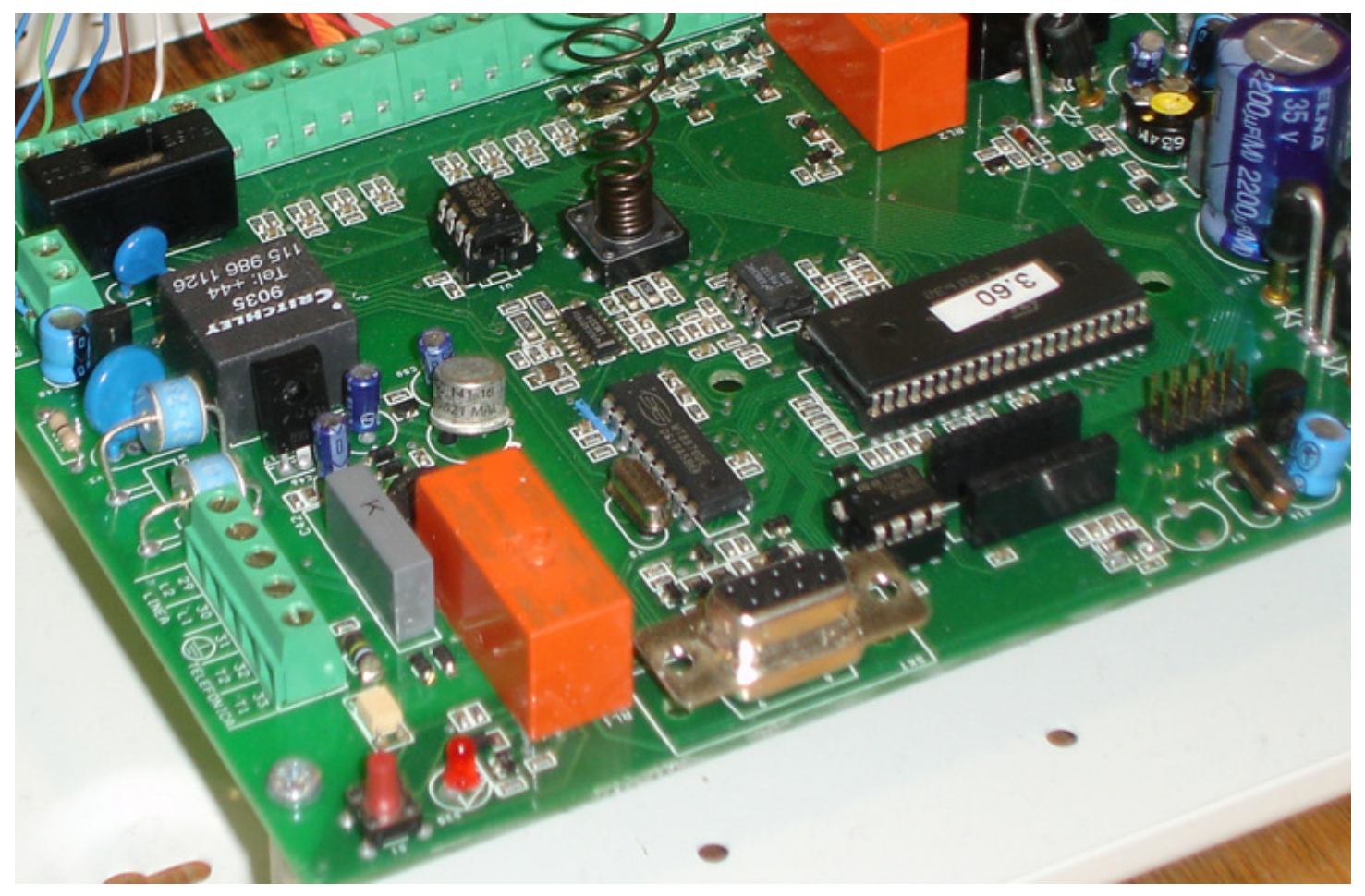

